\title{
THE DISTORTION OF JUSTICE FROM NON-STATE POWER
}

\author{
Aurelia Teodora DRAGHICI*, Dumitru GOŞA** \\ *"Nicolae Bălcescu" Land Forces Academy, Sibiu, Romanaia \\ **Service Dog Traning Centre "Dr. Aurel Greblea" Sibiu, Romania \\ teodora24a@yahoo.com,dan.gosa@yahoo.com
}

\begin{abstract}
The opportunity and the necessity of simplifying the texts of criminalization, the restoration in natural limits of the sanctioning treatment corroborated with the economic and social evolution, the national and international doctrine and jurisprudence, the necessity to ensure the legality, the impartiality, the independence and firmness in the application of the law, represented the justificatory premises of the legislator in order to amend The Penal Code with regard to the crimes against justice. The rationality for introducing new crimes such as "obstruction of justice" suppose to adapt criminal law to the realities of the democratic society, to the provisions of the European norms, the Romanian experience in the field proving that the means of criminal protection of justice were applied shyly and unconvincingly. The sources of obstruction of justice have not reduces but, instead, it amplified and gained new forms, some very subtle, in close contact with the international world.
\end{abstract}

Key words: crime, obstruction, justice, independence, power, abuse of power.

\section{Introduction}

The new Criminal Code of Romania appeared as a matter of particular importance in the legislative evolution of the Romanian state and our current society. With the aim of balancing the shortcomings of previous criminal regulations, it intends to create a modern legislative framework in line with criminal legal systems in countries with a tradition in this field (Italy, Germany, France, Spain), to include legislation of criminal law in its current special laws, to ensure the greatest respect for the principle of accessibility and predictability of the law.

The successful realization of the researches in the field of justice obstruction implies a good knowledge of the juridical phenomenon, the way of organizing the scientific activity, of the criminological research methods, as well as the process of evolution of a practical research in the field. To give priority to current concerns does not mean abandoning the theoretical DOI: $10.1515 / \mathrm{kbo}-2018-0084$

(C) 2015. This work is licensed under the Creative Commons Attribution-NonCommercial-NoDerivatives 3.0 License. researches (conceptual, fundamental or methodological) research, the fundamental studies being necessary for justice, because the solution of practical problems implies a certain level of development the science of law itself, because the doubt of general problems prevents the settlement of the private ones.

The importance of fundamental studies lead to their ability and function to generalize the particular information accumulated in order to reveal the general laws of existence of the researched phenomenon, which allows to know and influence the essential factors, because if the crime reaches pathological dimensions, and highlighted an increase in all aspects, there is a need for general macro-social remedies that hit the cause of the phenomenon, not just in the particular factors that only amplify or modify it [1].

Those who exercise unique or collective power express their own will, regardless their formation, the procedural and 
organizational rules from which it results, because the legitimacy of these authorities is different, where, without being able to transcend society, the legitimacy can only succeed as an expression of the social will.

In the relationship between the state and civil society, the part of the society that is not found in the political class, although the state has a dominant position, it can fulfill its role only in so far as it ensures the achievement of civil society objectives in the governance process.

In other words, the state exists as long as citizens believe in it. Otherwise, it loses its legitimacy, partially - as in the case of the Ceausescu's regime - or as a whole - as in the case of split, state confidence is conditioned by the formation of the rights and freedoms of the person, especially the citizens.

The more civil society is stronger the more state will be stronger. But this relationship is indissolubly linked to the defense and promotion of these rights and freedoms.

Beyond the increasing tendency of using the phrase "human right" as an ensemble of all legal rules that have as their object the protection of human beings in any circumstance, is considered that the expression "human rights" as subjective rights reflects better the legal status of the human individual.

International human rights instruments recognize what today is considered to be the concept of civil society in which citizens, the state enters into interdependence relations, can limit and control each other's actions in which citizens can claim their rights violated by the state and other political, economic, social, cultural factors.

Consequently, any violation of human rights and freedoms against one or more persons must be prevented and eliminated. Under the rules of international law, the state takes the necessary measures to ensure respect for human rights, creates institutions and forms in which every person values his rights towards other persons and even the state bodies [2].
Justice is one of the pillars that support any democratic society, and at the same time it is also a public service whose primary purpose is to satisfy the interests of society members.

In order for judges to assure the country's supremacy and to fulfill their responsibilities properly, they need a special status and guarantees: independence and impartiality.

Obstruction of justice in general from a legal point of view should be understood as an obligation of the state or person not to disregard the rights of the institution or other persons.

Obstruction can also be interpreted in the sense of changing the content or volume of action of the legal norm when the need to coordinate the divergent interests of the person, society and the state arises.

The change is usually directed towards decreasing the volume or limitation of the boundaries of the law, with the maintenance of the content.

Obstruction of the exercise of the right in the opinion of some authors is expressed by the narrowing of its volume (fewer cases of using this right), by the exclusion of optional signs which regulate the mechanism of realization of the law.

Justice is legitimate in protecting the individual or collective rights and freedoms of the person to whom the stability of any political regime depends, the consolidation and development of civil society and implicitly, of the state, essentially the prosperity of society.

Their sanctioning by law, as well as ensuring exercise in the process of government, without the intervention of justice for the removal of any violation, whenever possible as a result of permanent confrontation of interests in society, would corrupt the relationship, specific to democracy, between state and society.

Justice is a value in itself. If the function of the legislator as well as of the executive power is "for another", that is for society in general, more precisely for civil society and for every individual, otherwise 
degenerating into authoritarianism, dictatorship or totalitarianism, justice is a value in itself, because only in this way it can be legitimized as a space to protect the rights and freedoms conferred by law on citizens.

\section{The analysis of free access to justice. Obstructing it by non-state powers.}

The constitutional principle of free access to justice has been and remains, in practice, the first constitutional argument that anyone wishing to protect their legitimate rights and interests can pretend in their support on various occasions.

According to art. 1 par. (3) of the Constitution, Romania is characterized as a "rule of law, democratic and social, in which the dignity of man, citizens' rights and freedoms, the free development of human personality, justice and political pluralism are supreme values in the spirit of the democratic traditions of the Romanian people and the ideals of the Revolution of December 1989, and are guaranteed "[3].

In this context and of international acts that tend to exhaustively regulate human rights and fundamental freedoms, effective guarantee of their existence and observance is increasingly imperative.

Under the provisions of Art. 6 of the Convention for the Protection of Human Rights and Fundamental Freedoms, everyone has the right to a fair hearing of his case, which leads to good administration of justice: the right of access to an independent and impartial court established by law, the right to defense in the process, the principle of equality of arms, the principle of the contradictory nature of the process, the prompt execution of judgments, etc.

The fact that the free access to justice can be characterized as a constitutional principle was expressed by the Constitutional Court through one of its first reference decisions in the matter, namely the Decision of the Plenum no. 1/1994 on the free access of persons to the protection of their rights, freedoms and legitimate interests.

According to art. 21 par. (1) - (4) of the Constitution of Romania, in the content of Title II we find the fundamental rights, freedoms and duties: .... "Everyone can address justice for the defense of his rights, freedoms and legitimate interests.

No law may restrict the exercise of this right.

The parties have the right to a fair trial and to settle the cases in a reasonable time.

Special Administrative Jurisdictions are optional and free of charge "[3].

Its simple legal consecration, even at the supreme level, through the Constitution, does not ensure to the principle of free access to justice a real effectiveness as long as its practice encounters obstacles.

Access to justice must be effectively and efficacious ensured because an obstacle, actually, may break the stipulations of the Convention equally as a legal obstacle namely obligations under the Convention [4]. The civil or disciplinary liability of a judge for the way the law is interpreted, assessing facts or assessing evidence, except in cases of bad faith and serious negligence, can not be imputed.

Being the protectors of the independence and those who interpret the law, judges can not be the subject of disciplinary action on the basis of the simple exercise of their judicial functions, unless the unworthy conduct of a judge is proved.

Furthermore, it is important that judges can not be compelled to act under the threat of a sanction, including financial ones, whose existence may influence their decisions even unconsciously.

Judicial errors must be resolved by appealing, in the spirit of respecting jurisdiction and procedure, interpreting, applying the law or assessing the evidence.

That is why it is said that the judge's paradox consists in the fact that he depends on the state, the other powers, but must also control them; he represents both Power and Counterpower; he embodies the duality of righteousness / strength. 
This role of the judge has not only been preserved over time, but has also developed, but in order to fulfill his mission, the judge needs specific guarantees over the other powers, which can be subsumed to the idea of independence.

The right of access to justice is not an absolute right, any restriction being allowed as long as the right of access to justice is not undermined in its substance, the state having a margin of discretion on this line.

The obstruction of justice results from the action of political factors, for which reason the constitutional order is not to be conceived in a political regime in which, besides the juridical and state order, there is also a parallel and over-ordered order to the law and the state authorities, namely the political one, preeminent, and legal, subordinated.

The constitutional order can only be unique, and the independence of justice is its legal guarantee. That is why any obstruction of justice is implicitly an assault on the established constitutional order.

The concept of obstruction of justice consists in preventing it from fulfilling its social mission, on the basis of which it is legitimized as a state power. In other words, state power is expressed through the voice of justice provided that it is not obstructed in its legitimacy.

The court carries out its social legitimacy, that is, it ensures the application of the law in the legal spirit corresponding to the imperative of human justice, only in conditions of independence and impartiality.

Otherwise, the litigation of judgment, apparently a process, is actually "a business". In other words, by oblige the law, the process becomes a simple appearance, for the realization of a financial, political or other engineering, subordinated to the obtaining of a certain incorrect, unlawful result.

It follows that the obstruction of justice is characterized, first of all, by the misappropriation of the act of justice from its purpose, contrary to the legal spirit which it is called upon to express it.

The need for justice is inherent to the human nature and society. Therefore, the way of obstruction of justice, of injustice on the path of justice, has always existed.

Among these are the political processes through which, in a broad sense, not only those that result from a political defeat, but also those through which justice is prevented due to the social position of those involved, to political clientelism, etc. are understood. As such, partisan influence, no matter where it comes from, is a way of obstructing justice by breaking its independence.

For a purpose in itself, justice becomes, in such situations, a simple means. Apart from political corruption, any other way of corruption is basically the same, even if the solution is correct and legal, but as a result of occult influence and not as an expression of the rule of law, that of corruption, not of the spirit of justice.

Any act of interference in the activity of justice is, by its nature, at least an attempt to obstruct justice. It does not necessarily mean that it will be followed by the expected result, but in itself constitutes a similar danger in criminal law with the offense of danger.

And yet the means of diverting the procedures from their endpoint are much more numerous. Perhaps that is why in the Romanians' experience there is the proverb: "Better a crooked peace than a just trial." It's like a secular bitterness condensed in this proverb.

The obstruction of justice is not an exclusively modern phenomenon, but it may never have had a negative influence on the scale it can now have, owing to the unprecedented role of justice in the democratic order of modern society.

Starting with the recruitment of judges, prosecutors, police officers and auxiliary staff, with the organization of courts to avoid overcrowding, ensuring the financial independence of those involved in the act of justice, the solemnity of the judiciary and 
ensuring the necessary logistics, to the observance of the rules the legislative technique, especially on the systematization and coordination of legislation, obstruction of justice is a concept that goes beyond the exclusive framework of political, financial or other corruption.

It is obvious that since the judge "speaks the right", professional training and personal prestige are essential.

The unitary or, on the contrary, disorderly character of court practice, resulting in the violation of the equality of citizens against the law and the judiciary, as well as the prejudice to the predictability of the law, depends decisively on the professional training of judges, and at the same time is one of the most obvious features of obstruction of justice by misappropriating the act of justice from its purpose.

Also, the overcrowding of courts has the effect not only of delaying the settlement of cases, but also of the impossibility of the judge to ensure a deeper and deeper factual and legal situation for a fair solution.

The aim is to ensure an institutional balance between the courts for better administration of justice, since the judge's responsibility for the act of justice must be in line with the necessary organizational and logistical conditions to face this responsibility.

Otherwise, the obstruction of justice results from its own way of organization, is due to its internal causes, the effect of which is even worse, as not only they prepare the ground for the act of corruption, but also affect all disputes in the courts of judgment. Another way of obstructing justice comes from non-state powers, especially media, trade companies, economic interest groups, and pressure groups such as NGOs.

Of course, the Constitution enshrines freedom of expression, the right to information and freedom of assembly, nor can it be otherwise in a democratic society, but the same fundamental law enshrines the independence of justice, and therefore a beneficial balance must be ensured for the society between magistrates on the one hand, and opinion formers, on the other.
Relationships should be on the basis of mutual respect: the journalist should not claim to be a judge before the judge has "pronounced the right" and the magistrate judge or prosecutor - does not judge "the terror of the press".

Because the obstruction of justice can also come from the psychic pressure for pronouncing a solution that is not the result of its intimate conviction, but of the views of the manipulated or even spontaneous public image, and not as an expression of a free spirit of any prejudice.

Therefore, pressures on judges during the resolution of concrete causes are not and can not be such as to ensure their independence and impartiality.

At the same time, the obstruction of justice often comes in very varied forms from the parties involved in a concrete process. Beyond the more or less direct attempts to influence the judge who is called upon to resolve a particular case, there are many other ways: introducing informal requests and whose shortcomings are not remedied within the time limit set by the court; repeat requests for appeals, which sometimes target all the judges of a court in order to obtain a postponement of the case, because in such a case the petition for rescission is resolved by the higher court; unjustified wording of requests for resettlement on grounds of legitimate suspicion; requests for deferral without the invocation of reasonable grounds or doubtful reasons; requesting the opponent to be quoted by advertising, invoking in bad faith the lack of knowledge of his / her domicile; leaving the process out of the party's fault; to exercise all the remedies without the reasons invoked to fall within the scope of the law, only in order to prolong as much as possible the judgment; the introduction of successive enforcement requests to different court bailiffs in order to avoid suspension of execution in the first application or, on the contrary, the abusive exercise of appeals against execution.

All these and other similar events can be sanctioned by the court if abusive exercise 
of procedural rights is found, but they are also a means which hinders the work of the courts by imposing their role or prolonging the duration of the trial, and thus aspects of obstruction of justice [5].

\section{Conclusions}

In conclusion, starting from the idea that independent justice is the key element of the rule of law and democratic governance and is the instrument that must provide the necessary support for the other reforms, the Government must promote legislative, structural and procedural reforms in the judiciary.

The role of justice is both constitutional and legal, but above all social, an essential requirement of the legal spirit of our time, which is reflected in opinion polls.

In order to combat the phenomenon of obstruction of justice, it is necessary to have unitary, organizational, financial, institutional and legal concepts.

A unitary conception of the concept of obstruction of justice is necessary, and its establishment as well as measures to remove or diminish the factors that contribute to the obstruction of justice must be based on a thorough elaborated study.

Without justice, there can be no social peace. Justice is the ultimate remedy against injustice.

\section{References}

[1] Realizarea cercetărilor criminologice teoretice, Octavian Bejan, pag. 27.

[2] Drepturile și libertățile fundamentale ale omului - concept și clasificare, Berghian Ana Maria, pag. 2.

[3] Constituția României, pag. 1- 4.

[4] Convenția Europeană a Drepturilor Omului.

[5] Legeaz, Obstrucționarea justiției. 